\title{
A late-surviving apatemyid (Mammalia: Apatotheria) from the latest Oligocene of Florida, USA
}

Nicholas J Czaplewski, Gary S Morgan

A new species of Apatemyidae, Sinclairella simplicidens, is based on four isolated teeth that were screenwashed from fissure fillings at the late Oligocene Buda locality, Alachua County, Florida. Compared to its only congener Sinclairella dakotensis, the new species is characterized by upper molars with more simplified crowns, with the near absence of labial shelves and stylar cusps except for a strong parastyle on M1, loss of paracrista and paraconule on M2 (paraconule retained but weak on M1), lack of anterior cingulum on M1M3, straighter centrocristae, smaller hypocone on M1 and M2, larger hypocone on M3, distal edge of M2 continuous from hypocone to postmetacrista supporting a large posterior basin, and with different tooth proportions in which $\mathrm{M} 2$ is the smallest rather than the largest molar in the toothrow. The relatively rare and poorly known family Apatemyidae has a long temporal range in North America from the late Paleocene (early Tiffanian) to early Oligocene (early Arikareean). The new species from Florida significantly extends this temporal range by roughly $5 \mathrm{Ma}$ to the end of the Paleogene near the Oligocene-Miocene boundary (from early Arikareean, Ar1, to late Arikareean, Ar3), and greatly extends the geographic range of the family into eastern North America some $10^{\circ}$ of latitude farther south and $20^{\circ}$ of longitude farther east (about $2200 \mathrm{~km}$ farther southeast) than previously known. This late occurrence probably represents a retreat of this subtropically adapted family into the Gulf Coastal Plain subtropical province at the end of the Paleogene and perhaps the end of the apatemyid lineage in North America. 
1

2

3 A late-surviving apatemyid (Mammalia: Apatotheria) from the latest

4 Oligocene of Florida, USA

8 Nicholas J. Czaplewski ${ }^{1}$, Gary S. Morgan ${ }^{2}$

9 'Oklahoma Museum of Natural History, 2401 Chautauqua Avenue, University of Oklahoma,

10 Norman, OK, USA

11 2New Mexico Museum of Natural History, 1801 Mountain Road NW, Albuquerque, NM, USA

12

13

14 Corresponding author:

15 Nicholas J. Czaplewski

16 Oklahoma Museum of Natural History, 2401 Chautauqua Avenue, Norman, OK 73072, USA

17 Email address: nczaplewski@ou.edu

18 
20 A late-surviving apatemyid (Mammalia: Apatotheria) from the latest Oligocene of Florida, USA

22 Nicholas J. Czaplewski, Gary S. Morgan

\section{ABSTRACT}

25 A new species of Apatemyidae, Sinclairella simplicidens, is based on four isolated teeth that 26 were screenwashed from fissure fillings at the late Oligocene Buda locality, Alachua County,

27 Florida. Compared to its only congener Sinclairella dakotensis, the new species is characterized by upper molars with more simplified crowns, with the near absence of labial shelves and stylar cusps except for a strong parastyle on M1, loss of paracrista and paraconule on M2 (paraconule retained but weak on M1), lack of anterior cingulum on M1-M3, straighter centrocristae, smaller

31 hypocone on M1 and M2, larger hypocone on M3, distal edge of M2 continuous from hypocone

32 to postmetacrista supporting a large posterior basin, and with different tooth proportions in which

33 M2 is the smallest rather than the largest molar in the toothrow. The relatively rare and poorly

34 known family Apatemyidae has a long temporal range in North America from the late Paleocene 35 (early Tiffanian) to early Oligocene (early Arikareean). The new species from Florida 36 significantly extends this temporal range by roughly $5 \mathrm{Ma}$ to the end of the Paleogene near the 37 Oligocene-Miocene boundary (from early Arikareean, Ar1, to late Arikareean, Ar3), and greatly extends the geographic range of the family into eastern North America some $10^{\circ}$ of latitude

39 farther south and $20^{\circ}$ of longitude farther east (about $2200 \mathrm{~km}$ farther southeast) than previously

40 known. This late occurrence probably represents a retreat of this subtropically adapted family

41 into the Gulf Coastal Plain subtropical province at the end of the Paleogene and perhaps the end 42 of the apatemyid lineage in North America. 


\section{INTRODUCTION}

44 Apatemyids are a unique family of small mammals that are uncommon in Paleogene

45 localities of North America and Europe. Their cranial and postcranial anatomy are known in

46 North America from Paleocene specimens of Labidolemur kayi (Bloch \& Boyer, 2001; Silcox et

47 al. 2010) and an Eocene specimen of Apatemys chardini (von Koenigswald et al., 2005a), while

48 the unusual dental, jaw, and hand adaptations of these and a few skeletons from Europe indicate

49 that apatemyids evolved convergently with living marsupials in the genus Dactylopsila

50 (Petauridae; striped or long-fingered possums) of New Guinea and northeastern Australia, and

51 with the living primate Daubentonia (Daubentoniidae; aye-aye) of Madagascar (McKenna, 1963;

52 West, 1973; von Koenigswald \& Schierning, 1987; von Koenigswald et al., 2005; Rose, 2006).

53 Aspects of apatemyids' ecology, too, were probably similar to these living mammals as well as

54 possibly that of the extinct Oligocene-Miocene metatherian Yalkaparidon of Australia (Beck,

55 2009). Like striped possums and the aye-aye, the striped possum-sized apatemyids are presumed

56 (1) to have been arboreal and insectivorous, (2) to have used their pincerlike upper and lower

57 incisors to tear loose bark from trees or rip open rotting wood that might harbor wood-boring

58 insects, and (3) to have used two elongated manual digits to help find and extract the insects

59 from cavities in the wood. The overall time range of the Apatemyidae as presently known spans

60 virtually the entire Paleogene, from the early Paleocene to Eocene in Europe and from the early

61 Paleocene to the late Oligocene (early Arikareean) in North America (McKenna \& Bell, 1997;

62 Rose, 2006; Gunnell et al., 2008). Apatemyids are unknown from other continents. The earliest

63 North American genera in this poorly known family are Jepsenella and Unuchinia. Jepsenella is

64 known from the late Torrejonian, Unuchinia from the Torrejonian and Tiffanian (Paleocene), and

65 Labidolemur from the early Tiffanian. West (1973) reviewed the North American Eocene and 
66 Oligocene Apatemyidae (not the Paleocene taxa) and reduced several previously named genera

67 (Apatemys, Labidolemur, Stehlinius, Stehlinella, Teilhardella, and Sinclairella) and species to

68 just two genera: Apatemys, with two highly variable species, and Sinclairella, with a single

69 species. So defined, Apatemys has a long temporal range of perhaps 20 million years from the

70 late Paleocene (Tiffanian) until the late middle Eocene (Duchesnean) in North America. All

71 known occurrences of this family in North America are in the western interior or Pacific coastal

72 parts of the continent, in Saskatchewan, Canada, and the states of Montana, Wyoming, South

73 Dakota, Nebraska, Utah, Colorado, New Mexico, and California (West, 1973; Storer, 1996).

74 Some authors (e.g., McKenna \& Bell, 1997) followed West's (1973) synonymy, but Russell et

75 al. (1979) asserted that Labidolemur should be maintained as a separate genus for the species $L$.

76 kayi. Gingerich \& Rose (1982) and Gingerich (1982) also retained Labidolemur for other

77 Paleocene species. Rose (2006) recognized Apatemyidae as the only family within the order

78 Apatotheria, containing six genera, Unuchinia, Jepsenella, Labidolemur, Apatemys, Heterohyus,

79 and Sinclairella. We follow Rose's (2006) taxonomy herein but also recognize in addition the

80 recently described European genus Carcinella (von Koenigswald et al. 2009).

81 The latest known apatemyid is Sinclairella dakotensis Jepsen, 1934, the only recognized

82 member of its genus. Sinclairella occurred in the Duchesnean (late middle Eocene), Chadronian

83 (late Eocene), Orellan (early Oligocene), Whitneyan (early Oligocene) and early Arikareean

84 (early Oligocene) of western North America. Two of the earliest records are identified only as

85 Sinclairella sp. (Storer, 1995, 1996); later occurrences are published as Sinclairella dakotensis.

86 Ages and localities of occurrence (Fig. 1; ages here are adjusted to reflect those provided by

87 Albright et al., 2008; Janis, Gunnell \& Uhen, 2008:appendix 1) are: Duchesnean: Lac Pelletier

88 Lower fauna, Saskatchewan (Storer, 1995); Chadronian: Calf Creek Local Fauna (LF), 
89 Saskatchewan (Storer, 1996), Flagstaff Rim area and Bates Hole, Wyoming (Emry, 1973; West, 90 1973), the type locality at Big Corral Draw, South Dakota (Jepsen, 1934), Medicine Pole Hills

91 Local Fauna, North Dakota (Pearson \& Hoganson, 1995), Raben Ranch and Twin Buttes Local

92 Faunas, and harvester ant mounds in Sioux County, Nebraska (Clemens, 1964; Ostrander, 1985 ,

93 1987); Orellan: Logan County and Weld County, Colorado (Clemens, 1964), and Shannon

94 County, South Dakota (West, 1973); Whitneyan-early Arikareean: Wh2-Ar1, Harris Ranch

95 badlands, Fall River County, South Dakota (as Sinclairella cf. S. dakotensis; Simpson, 1985);

96 Ar1, Gering Fauna, Nebraska (Gunnell et al., 2008); Ar1, Unit C of Turtle Cove Member, John

97 Day Formation, Oregon (29.75-28.8 Ma; Cavin \& Samuels, 2012). Thus, through Sinclairella

98 dakotensis, the North American apatemyid lineage continued into the earliest Arikareean (Ar1).

99 We report the occurrence of the apatemyid lineage for the first time in the eastern half of

100 North America, and about 5 million years later than the previous latest known occurrences. The

101 occurrence consists of four unassociated, isolated teeth of an apatemyid similar to Sinclairella

102 dakotensis that were found in the Buda locality, Florida, which yielded a mammalian fauna of

103 latest Oligocene age (early late Arikareean, Ar3). The Florida Sinclairella differs in size and

104 qualitative dental characters from $S$. dakotensis, and clearly represents a distinct new species.

105 Herein we use the revised chronostratigraphy and biochronology of the Arikareean

106 NALMA of Albright et al. (2008) as recorded in the John Day Formation of Oregon. These

107 authors placed the base of the Arikareean NALMA and subbiochron Ar1 at approximately 30

108 Ma, with basal temporal boundaries of the other subbiochron intervals as follows: Ar2, $28 \mathrm{Ma}$;

$109 \mathrm{Ar}$, $26 \mathrm{Ma}$; Ar4, $23 \mathrm{Ma}$; base of Hemingfordian NALMA and Hel subbiochron, 18.5 Ma. Of

110 particular significance to the Buda Local Fauna, Albright et al. (2008) established the boundary

111 between the Ar2 and Ar3 at about $26 \mathrm{Ma}$ (late Oligocene), whereas Tedford et al. (2004) placed 
112 this same boundary at about $23 \mathrm{Ma}$ (earliest Miocene). We also use the broader terms, early

113 Arikareean (Ar1 and Ar2), including the earliest Arikareean (Ar1; 30-28 Ma) and late early

114 Arikareean (Ar2; 28-26 Ma), and late Arikareean (Ar3 and Ar4), including the early late

115 Arikareean (Ar3; 26-23 Ma) and latest Arikareean (Ar4; 23-18.5 Ma). Rincon et al. (2015)

116 recently subdivided the Arikareean somewhat differently, still recognizing the Ar1-Ar4

117 subbiochrons with the same boundaries as in Albright et al. (2008), but using the term early

118 Arikareean only for Ar1 faunas, middle Arikareean for Ar2, Ar3, and earliest Ar4 faunas, and

119 late Arikareean for most Ar4 faunas.

121 Locality and Mammalian Biochronology

122 The Buda Local Fauna (LF) was found in the Buda Quarry, an abandoned limestone mine 123 located about $8 \mathrm{~km}$ southwest of High Springs, Alachua County, northern peninsular Florida $124\left(29^{\circ} 45^{\prime} \mathrm{N}, 82^{\circ} 38^{\prime} \mathrm{W}\right)$. The Buda LF, discovered in February 1965 by S. D. Webb, N. Tessman, J.

125 S. Waldrop, and E. Kayworth, occurred in a clay-filled sinkhole formed in Eocene marine

126 limestone of the Crystal River Formation. The fossiliferous sinkhole deposit, long since

127 destroyed by mining operations, consisted of three shallow vertical chambers from 1 to $3 \mathrm{~m}$ in

128 diameter that probably shared a common opening. The remains of large mammals from the Buda

129 Quarry were found mostly in clays in spoil piles, whereas the small mammals were

130 screenwashed from pockets of clayey sand. The fossils occurred primarily as isolated teeth and

131 disarticulated postcranial bones (Frailey, 1979).

132 About 20 species of mammals are presently recognized in the Buda fauna (Table 1).

133 Frailey (1979) reported 12 taxa of large mammals: five carnivores (the amphicyonid

134 Daphoenodon notionastes and the canid Bassariscops achoros, both described as new species, 
135 the canid Cynarctoides sp., a mustelid, and a nimravid); two perissodactyls (the small

136 chalicothere Moropus sp. and an indeterminate equid); and five artiodactyls (the tayassuid

137 Cynorca, a phenacocoeline oreodont, two unidentified camelids, and the hypertragulid

138 Nanotragulus loomisi). The most abundant mammal at Buda is the tiny artiodactyl Nanotragulus

139 loomisi.

140 In a systematic review of the borophagine canids, Wang, Tedford \& Taylor (1999)

141 reexamined the canid sample from Buda, and reassigned several specimens to different taxa than

142 in Frailey (1979). Wang, Tedford \& Taylor (1999) recognized three small borophagine canids

143 from Buda: Phlaocyon achoros (referred to Bassariscops by Frailey, 1979), Cynarctoides lemur

144 (including some specimens originally referred to Bassariscops achoros by Frailey, 1979), and

145 Cormocyon cf. C. copei. Phlaocyon achoros is known only from Buda, the type locality, but this

146 species is similar to P. multicuspus from the late Arikareean of Wyoming (Wang, Tedford \&

147 Taylor, 1999) and P. taylori from the early late Arikareean (Ar3) Brooksville 2 LF in Florida

148 (Hayes, 2000). Cynarctoides lemur is primarily an early Arikareean species, including samples

149 from the John Day Formation in Oregon and the Sharps Formation in South Dakota. Wang,

150 Tedford \& Taylor (1999) tentatively referred a single isolated tooth from Buda to Cormocyon

151 copei, a species best known from the early Arikareean of Oregon. In a paper reviewing the

152 earliest North American chalicotheres, Coombs et al. (2001) referred the small Buda chalicothere

153 to Moropus cf. M. oregonensis, a species also known from the early late Arikareean (Ar3) of

154 Oregon and Texas.

155 Buda also yielded a significant small mammal fauna that remains mostly unstudied. Rich

$156 \&$ Patton (1975) reported an isolated lower molar of the erinaceine hedgehog Amphechinus from

157 Buda, which Hayes (2000) reidentified as the erinaceid Parvericius. Other small mammals from 
158 Buda include the new apatemyid described herein, the geolabidid insectivore Centetodon cf. $C$.

159 magnus, a large species of emballonurid bat, and three rodents, the jimomyid Texomys, the large

160 eomyid Arikareeomys, and the heteromyid Proheteromys. The two teeth of Centetodon from

161 Buda represent one of the youngest known records of this genus. Korth (1992) described the new

162 species Centetodon divaricatus from the McCann Canyon LF in Nebraska, which he placed in

163 the early late Arikareean (Ar3). However, Tedford et al. (1996, 2004) considered the McCann

164 Canyon LF to be late early Arikareean (Ar2), equivalent in age to faunas from the Monroe Creek

165 Formation. The youngest previous record of Centetodon is based on two early Arikareean

166 specimens of C. magnus from the Monroe Creek Formation in the Wounded Knee area of South

167 Dakota (Lillegraven, McKenna \& Krishtalka, 1981). Korth (1992) also described a new genus

168 and species of large eomyid rodent, Arikareeomys skinneri, from McCann Canyon. The only

169 other records of Arikareeomys are represented by an undescribed species from four Florida

170 Arikareean faunas, Buda, Cow House Slough, SB-1A/Live Oak, and White Springs (Morgan,

171 1993; MacFadden \& Morgan, 2003). Texomys occurs in both Buda and the correlative Ar3

172 Toledo Bend LF in easternmost Texas. These are apparently the only Arikareean records of

173 Texomys, which is otherwise known from the Hemingfordian of Panama and the Barstovian of

174 Texas and Louisiana (Slaughter, 1981; Albright, 1996; MacFadden et al., 2014).

175 Frailey (1979) considered the Buda LF to be late Arikareean in age. Tedford et al. (1987)

176 placed this fauna in the early part of the late Arikareean (Ar3 of Woodburne \& Swisher, 1995).

177 In comparisons with other Arikareean faunas from Florida and Texas, Albright (1998) and Hayes

178 (2000) agreed with Tedford et al. (1987) in placing the Buda LF in the early late Arikareean

179 (Ar3, 24-22 Ma). Tedford et al. (2004) gave the same approximate age range for Buda (24-23

$180 \mathrm{Ma}$ ), but placed this fauna in the late early Arikareean (late Ar2). Based on the revised age 
181 ranges for the subdivisions (subbiochrons) of the Arikareean NALMA presented by Albright et

182 al. (2008), the Buda LF would be placed in the early late Arikareean (late Ar3; 24-23 Ma; latest

183 Oligocene) (Fig. 2).

184 Although a number of mammals from the Buda LF are age-diagnostic, depending upon

185 the genus or species, they seem to provide somewhat conflicting evidence pertaining to the site's

186 age. Some mammals from Buda suggest a late early Arikareean age (Ar2), whereas other taxa

187 are indicative of early late Arikareean faunas (Ar3). Furthermore, most of the previous papers

188 that have discussed the mammalian biochronology of Buda (Frailey, 1979; Tedford et al., 1987,

189 2004; Albright, 1998; Hayes, 2000) were written prior to the significant changes in the

190 boundaries for the subbiochrons of the Arikareean NALMA proposed by Albright et al. (2008).

191 Mammals from Buda indicating an Ar3 age are Moropus, Daphoenodon, and Texomys. Moropus

192 and Daphoenodon make their first appearance in the John Day sequence at approximately the

193 same time, in the Ar3 at about $25 \mathrm{Ma}$ (Albright et al., 2008). Texomys does not occur in the John

194 Day Formation, but all other records of this genus are from late Arikareean (Ar3) or younger

195 faunas (Albright, 1996). As noted above, Texomys has a southern distribution, including Florida,

196 Louisiana, Texas, and Panama, and the earliest occurrences of this genus are in Buda and the

197 correlative Ar3 Toledo Bend LF on the Gulf Coastal Plain of Texas (Albright, 1996).

198 Mammals from Buda indicative of an early Arikareean (Ar1/Ar2) age are the new

199 apatemyid, Centetodon, Cynarctoides lemur, Cormocyon cf. C. copei, Arikareeomys, and

200 Nanotragulus loomisi. Excluding Buda, apatemyids are otherwise unknown after the earliest

201 Arikareean (Ar1) in North America (West, 1973). The youngest records of Centetodon are from

202 the Wounded Knee Fauna of South Dakota (Lillegraven, McKenna \& Krishtalka, 1981) and the

203 McCann Canyon LF of Nebraska (Korth, 1992), both of which are correlatives of the Monroe 
204 Creek Fauna of late early Arikareean age (Ar2). Wang, Tedford \& Taylor (1999) referred

205 specimens of borophagine canids from Buda to Cynarctoides lemur and Cormocyon cf. C. copei,

206 species originally described from the early Arikareean (Ar1/Ar2) Turtle Cove Member of the

207 John Day Formation in Oregon. The fauna from the type locality for Arikareeomys, the McCann

208 Canyon LF in Nebraska, was considered a correlative of the late early Arikareean (Ar2) Monroe

209 Creek Fauna by Tedford et al. $(1996,2004)$. In addition to Buda, the three other faunas from

210 Florida in which Arikareeomys occurs, Cow House Slough, White Springs, and SB-1A/Live

211 Oak, have been considered late early Arikareean in age (Frailey, 1978; Morgan, 1993; Hayes,

212 2000; MacFadden \& Morgan, 2003). However, these three faunas, like Buda, would now be

213 considered early late Arikareean (Ar3) based on the placement of the lower boundary for the Ar3

214 at $26 \mathrm{Ma}$ (Albright et al., 2008). The tiny ruminant Nanotragulus loomisi from Buda, as well as

215 the Brooksville 2 LF in Florida, is most similar to samples of $N$. loomisi from early Arikareean

216 faunas in the northern Great Plains (Frailey, 1979; Hayes, 2000).

217 Albright $(1996,1998,1999)$ considered Buda and the Toledo Bend LF in easternmost

218 Texas to be correlative early late Arikareean (Ar3) faunas based on the co-occurrence of

219 Daphoenodon notionastes, Moropus, and Texomys. However, these two faunas do have different

220 species of Nanotragulus. Buda has the small early Arikareean species N. loomisi, whereas

221 Toledo Bend has a larger species, similar to $N$. ordinatus and N. matthewi, that is more common

222 in the late Arikareean (Frailey, 1979; Albright, 1999; Hayes, 2000).

223 The conflicting evidence from certain taxa indicating a late early Arikareean (Ar2) age

224 and other taxa indicating an early late Arikareean (Ar3) age for Buda has led several workers to

225 regard Buda and other Florida Arikareean faunas (e.g., Brooksville 2) as "medial Arikareean,"

226 essentially combining Ar2 and Ar3 (e.g., Albright, 1998; Wang, Tedford \& Taylor, 1999; Hayes, 
227 2000). Rincon et al. (2015) used the term "middle Arikareean" for the time interval between

228 about 28 and $22 \mathrm{Ma}$, encompassing the Ar2, Ar3, and early part of Ar4. The presence of

229 Centetodon cf. C. magnus, the John Day canids Cynarctoides lemur and Cormocyon cf. C. copei,

230 Arikareeomys, and Nanotragulus loomisi provides the most compelling biochronologic evidence

231 for a late early Arikareean (Ar2) age for the Buda LF. None of these species occurs after the

232 early Arikareean in western faunas, and Sinclairella is otherwise unknown in faunas younger

233 than earliest Arikareean (Ar1). However, Dapheonodon and Moropus are unknown from early

234 Arikareean faunas, with their earliest well-dated appearance in the John Day Formation in

235 Oregon in the early late Arikareean (Ar3) at about $25 \mathrm{Ma}$ (Albright et al., 2008). Together with

236 the records from the John Day Formation and the Toledo Bend LF in Texas (Albright, 1998,

237 1999; Albright et al., 2008), Buda appears to represent one of the earliest occurrences of both

238 Daphoenodon and Moropus. Pending a more detailed biochronology of Florida Arikareean

239 faunas, we tentatively regard the Buda LF as early late Arikareean in age (Ar3; 25-23 Ma).

\section{METHODS AND MATERIALS}

The electronic version of this article in Portable Document Format (PDF) will represent a published work according to the International Commission on Zoological Nomenclature (ICZN),

244 and hence the new names contained in the electronic version are effectively published under that

245 Code from the electronic edition alone. This published work and the nomenclatural acts it

246 contains have been registered in ZooBank, the online registration system for the ICZN. The

247 ZooBank LSIDs (Life Science Identifiers) can be resolved and the associated information viewed

248 through any standard web browser by appending the LSID to the prefix http://zoobank.org/. The

249 LSID for this publication is: urn:lsid:zoobank.org:pub:76E08309-BD0A-4665-AA39- 
250 D36450AAE5FF. The online version of this work is archived and available from the following

251 digital repositories: PeerJ, PubMed Central and CLOCKSS.

252 Abbreviations used herein: UF, Florida Museum of Natural History, University of

253 Florida, Gainesville, Florida, USA; YPM PU, Yale University Peabody Museum of Natural

254 History-Princeton University, New Haven, Connecticut, USA; NALMA, North American Land

255 Mammal Age; Ar, Arikareean North American Land Mammal Age; He, Hemingfordian North

256 American Land Mammal Age; LF, local fauna; Ma, millions of years before present; APL,

257 anteroposterior length; TW, transverse width; N, sample size.

258 Dental terminology follows that used by Van Valen (1966) and Silcox et al. (2010).

259 Specimens were measured and photographed at the Oklahoma Museum of Natural History,

260 University of Oklahoma, using an Olympus SZX9 stereomicroscope with an eyepiece reticle,

261 and a Zeiss digital scanning electron microscope, respectively. Anteroposterior length (APL) was

262 the greatest length measured anteroposteriorly along the labial side of the tooth; transverse width

263 (TW) was the greatest width of the tooth measured transversely from lingualmost extent to the

264 labialmost extent. Additional tooth measurements were made in a manner following von

265 Koenigswald et al. (2009:table 4): Width 2 was the diagonal width from the lingual base of the

266 protocone to the edge of the tooth labial to the paracone; Width 3 was the diagonal width from

267 the lingual base of he protocone to the edge of the tooth labial to the metacone; Width 4 was the

268 diagonal width from the posterolingual corner of the talon at the hypocone to the anterolabial

269 corner of the tooth at the parastyle.

270

271

272

RESULTS 
274 Systematic Paleontology

275

276

277

SINCLAIRELLA Jepsen, 1934

278

SINCLAIRELLA SIMPLICIDENS, new species.

279

280

Holotype. UF 97383, right M2 (Fig. 3).

281

Hypodigm. Type and UF 97385, right M1; UF 97384, damaged right M2; UF 97382, left

282 M3.

283

Locality and Horizon. Buda locality, Alachua County, Florida. Fissure fillings in solution 284

cavities formed within the Crystal River Formation, early late Arikareean (Ar3) land mammal 285 age, latest Oligocene (see Locality and Mammalian Biochronology section).

Etymology. simplicis, Latin, "simple;" dens, Latin, "tooth;" in reference to the simplicity

287 of the crowns of the upper molars.

288 Diagnosis. Upper molars simpler than in Sinclairella dakotensis and all other known 289 apatemyids in that they lack conules except for a weak paraconule on M1, anterior cingula are 290 absent, labial stylar cusps are absent except for a strong parastyle on M1, and stylar shelves 291 (labial cingula) are virtually absent on all three upper molars, the only remnant being a weak 292 shelf labial to the paracone on M3 that is much less prominent than that on any other known 293 apatemyid. Hypocones on M1 and M2 smaller and on M3 larger than in S. dakotensis.

294 Centrocristae (postparacrista and premetacrista) on upper molars straighter than in S. dakotensis. 295 M2 relatively small, having about the same occlusal area as M1 and less than M3, about as long 
296 as wide, transversely much narrower than the M2 in S. dakotensis, and with distal edge

297 continuous from hypocone to postmetacrista supporting a large posterior basin. In size, molars

298 are slightly smaller than in S. dakotensis (Table 2).

299 Description. Sinclairella simplicidens is known only by the four isolated teeth listed

300 above (Fig. 3). The four teeth represent a minimum of two individuals based on two right M2s;

301 one of these, UF 97384, also shows more wear than the holotype UF 97383. Size is smaller than

302 in S. dakotensis and larger than in Apatemys uintensis. The molars are brachydont and generally

303 lack sharp crests, although the centrocrista forms a fairly strong ridge between the paracone and

304 metacone of each molar. In occlusal view the centrocrista, preparacrista and postmetacrista form

305 a nearly straight ridge on each upper molar. Paracones and metacones are moderately tall cusps

306 that are oval in occlusal aspect. The molars are simplified by comparison with those of all other

307 known apatemyids.

308 The M1 is roughly quadrangular in occlusal outline, with a prominent anterior projection

309 formed by the paracone and parastyle. The three main cusps, protocone, paracone, and metacone

310 are roughly equal in size. A smaller hypocone is present on the posterolingual corner of the

311 tooth; it bears weak, short ridges extending anteriorly and posterolabially from its rounded

312 summit. A small, weak paraconule occurs lingual to the paracone. A preprotocrista extends from

313 the protocone anteriorly and labially to the paraconule and parastyle, forming a shelf. A short,

314 notched preparacrista connects the parastyle and paracone. In occlusal view the labial cusps

315 (parastyle-paracone-metacone) are connected by crests (preparacrista-centrocrista-

316 postmetacrista) and aligned nearly straight from anterior to posterior.

Two specimens of M2 are available, the holotype UF 97383 and UF 97384 . UF 97384 is

318 somewhat damaged, with minor breakage on its distal edge and preprotocrista, and missing small 
319 portions of its enamel on the posterior edge and on the apex of the protocone and labial edge due

320 to breakage or abrasion. The M2 has three main cusps, with the protocone appearing somewhat

321 larger than the paracone and metacone. A small, low hypocone lends a squarish outline to the

322 posterior half of the tooth. The trigon basin between the three main cusps is relatively shallow

323 and featureless. The hypocone is small and less projecting posteriorly than in S. dakotensis.

324 Instead the distal edge of the tooth is nearly straight to barely convex between the hypocone and

325 metacone. A preprotocrista curves forward from the protocone toward the anterior of the

326 paracone, forming a small shelf that closes off the trigon basin anteriorly. There is no parastyle,

327 stylar shelf, or cingula. The preparacrista and centrocrista are aligned nearly straight anterior to

328 posterior in occlusal view; postmetacrista is weak or absent.

329 The M3 has three main cusps, with the protocone somewhat larger than the subequal

330 paracone and metacone. The hypocone is fairly large, low, rounded, and curved, and is more

331 elongated transversely than in M1 and M2, forming a rounded posterolingual corner on the tooth.

332 As in M1 and M2, the preprotocrista forms a shelf between the protocone and the preparacrista.

333 There is no parastyle. The preparacrista and centrocrista are aligned straight anterior to posterior

334 along the labial half of the tooth; postmetacrista is absent. In occlusal outline, the paracone

335 bulges anteriorly and labially, with a weak labial shelf, but there is no hint of a shelf labial to the

336 metacone. Posterior edge of the M3 is nearly straight, as in M2.

337 Comparisons. The Buda LF apatemyid consists of four unassociated upper molars representing

338 the loci M1, M2, and M3. The Buda LF specimens can be confidently assigned to the

339 Apatemyidae, whose upper molars are characterized as being relatively low-crowned,

340 transversely rather narrow, bearing three main cusps plus a small hypocone, conules absent or

341 very small, and moderate stylar shelves lacking mesostyles but having strong parastyles (Rose, 
342 2006; Gunnell et al., 2008). The genus Sinclairella is further characterized as being relatively

343 large, with upper molars squarish, lacking ectoflexi, and bearing large hypocones (West, 1973).

344 The genus presently includes only one species, Sinclairella dakotensis. Given the differences in

345 the few known upper molars of S. simplicidens from those of Sinclairella dakotensis it is

346 possible that the apatemyid in the Buda LF represents not only a new species but a new genus.

347 Many named apatemyids are based on more complete material, often lower jaws with teeth,

348 skulls, or even complete or partial skeletons. However, until more and better specimens are

349 found and the diagnosis can be expanded with additional characters of the skeleton, skull, or at

350 least the other teeth besides upper molars, it seems parsimonious at present to consider the

351 Florida apatemyid as a new species.

352 Silcox et al. (2010) provided the only available phylogenetic analysis of Apatemyidae,

353 and included $S$. dakotensis in their study. In the characters they developed that can be assessed in

354 the Buda LF molars, two that pertain to the upper molars were found to be synapomorphies of

355 the Apatemyidae: M1 metaconule absent, and M1 paraconule appressed to paracone. In the Buda

356 M1s, metaconules are absent and the paraconule is reduced but situated near the paracone.

357 Several of Silcox et al.'s (2010) characters pertaining to the upper molars appeared as

358 synapomorphies supporting a node containing S. dakotensis and Heterohyus nanus, a European

359 taxon. These synapomorphies are: M1 protocone position central on the tooth, M2 hypocone

360 large, similar in size to the protocone, M3 hypocone large, upper molar stylar shelf narrow

361 (buccal cingulum only) or absent, molar cusps relatively blunt (bunodont). Relative to these

362 character states, the Buda LF specimens resemble S. dakotensis and H. nanus in sharing the M1

363 protocone position, narrow stylar shelves, and blunt cusps, but differs from them in having the

364 M2 hypocone distinctly smaller than the protocone, and the M3 hypocone small instead of large. 
365 Sinclairella dakotensis showed no apomorphies in the upper molars among apatemyids in their

366 study (Silcox et al., 2010); however, another European taxon, Carcinella sigei, showed an upper

367 molar autapomorphy in having the M1 metaconule and paraconule both weak or absent. This

368 condition, too, differs in the Buda LF M1, which has a weak paraconule and no metaconule.

369 Fossils of apatemyids are generally rare or uncommon in early Paleogene faunas. When

370 they are encountered, the most commonly found elements are lower jaws or fragments; maxillary

371 fragments and upper molars are quite rare in collections (West, 1973; Fig. 4). Thus, the Florida

372 sample is rather unusual in that it consists of isolated upper molars and no lower teeth. When

373 West (1973) reviewed all the North American Eocene and Oligocene apatemyids, he studied the

374 type specimen of $S$. dakotensis, YPM PU 13585. The type included the only cranium of the

375 species and was one of the few available specimens including upper molars (West, 1973). The

376 holotype YPM PU 13585 was lost in the mail in 1976 and had not been molded before it was

377 loaned (D. Brinkman and M. Fox, pers. comm. 2001). As a result, our comparisons of $S$.

378 simplicidens were necessarily based on the diagnoses, illustrations, and measurements of $S$.

379 dakotensis upper molars provided in Jepsen (1934), Clemens (1964), and West (1973).

380 The external (labial) shelf in Sinclairella dakotensis (and other earlier apatemyids) forms

381 prominent projections anterolabial to the paracone in M2 and M3 and labial to the metacone in

382 M2 (Fig. 4). Jepsen (1934) noted that the stylar shelf in M1 supported a number of small

383 cuspules, the largest of which occurred in the metastyle and mesostyle positions (although he

384 commented that these cuspules were not true styles). The labial shelf in M2 is wide and elevated

385 as an irregular ridge along its outer border. In M3 the external cingulum is present anterolabial to

386 the paracone but absent or minute labial to the metacone. Clemens (1964) noted no significant

387 differences between Chadronian and Orellan specimens of $S$. dakotensis from the Great Plains 
388 and the type specimen of $S$. dakotensis, although he did mention minor differences in details of

389 crown morphology of the upper molars. In a maxillary fragment from Colorado (University of

390 Kansas Museum of Natural History 11210), the M1 has a smooth stylar shelf with no evidence of

391 stylar cusps, unlike the holotype, and the M2 in occlusal view has a stylar shelf represented by

392 anterolabial (with a small parastyle) and posterolabial projections separated by a distinct

393 ectoflexus, and a convex rather than concave posterior margin. Another Orellan specimen

394 (University of Colorado Museum, Boulder, no. 20173), an isolated M2 from Colorado, lacks the

395 stylar cusps in the position of a parastyle and mesostyle (Clemens, 1964), but also retains

396 anterolabial and posterolabial projections separated by a deep ectoflexus.

397 Compared to S. dakotensis, the crowns of the upper molars of S. simplicidens are even

398 less distinctly cuspate and more simplified, with the bases of the cusps merging into smooth-

399 bottomed valleys between cusps. The crests extending from the major cusps are somewhat better

400 developed. Labial shelves are essentially absent and they completely lack cuspules in $S$.

401 simplicidens compared to S. dakotensis. Although the M1 retains a strong parastyle anterior to

402 the paracone, the only remnant of a labial shelf in $S$. simplicidens is a smooth rounded shelf

403 anterolabial to the paracone in M3. Unlike S. dakotensis, parastyles are absent on M2 and M3 in

404 S. simplicidens. Sinclairella simplicidens lacks other structures that are present in S. dakotensis,

405 such as a paraconule on M2, a lingual cingulum anterior to the base of the protocone in M1, and

406 a low ridge posterolingual to the base of the metacone in M1. Relative to the other upper molars,

407 the M2 is the smallest molar in the row in S. simplicidens, whereas M2 is the largest upper molar

408 in S. dakotensis (Fig. 4). The hypocone on M2 in S. simplicidens is much smaller than that in $S$.

409 dakotensis. The hypocone on M3 is present as an elongated ridge in S. simplicidens, whereas it is

410 essentially absent in S. dakotensis. 


\section{DISCUSSION}

413 With the description of $S$. simplicidens from the latest Oligocene, the overall time range

414 of existence of the Apatemyidae now virtually spans the entire Paleogene (early Paleocene-late

415 Oligocene) in North America and from the early Paleocene to late Eocene in Europe.

416 Apatemyids are generally uncommon in early Paleogene faunas in North America, although, as

417 West (1973) noted, they are not quite as rare as Simpson (1954) and others had previously

418 believed. This paper records the only known Paleogene occurrence of an apatemyid in eastern

419 North America. The Florida apatemyids were discovered some $10^{\circ}$ of latitude farther south and $42020^{\circ}$ of longitude farther east in North America than previously known.

421 Given their unusual niche as "mammalian woodpeckers" or ecological equivalents of striped 422 possums or aye-ayes, apatemyids probably required stable, mature forests, where deposition, 423 burial, and preservation conditions are usually poor. They may also have required numerous 424 dead snags or at least dead wood in which to forage, or some other specialized niche or habitat 425 feature of restricted availability that could have limited their abundance. Regarding the less 426 distinctly cuspate and more simplified crowns, and the singularly small M2 proportions relative 427 to M1 and M3 in S. simplicidens, these distinctions might point to some unknown difference in 428 the species' trophic biology from S. dakotensis and other Apatemyidae. Alternatively, it could 429 represent a phylogenetic trend unique to the North American lineage of which S. simplicidens is 430 a part, because there does not seem to be a general trend among North American apatemyids 431 toward simplification of the upper molars.

432 The Buda fauna preserves certain genera of mammals that are also known in Arikareean 433 faunas of the northern Great Plains and/or the John Day Formation of Oregon (e.g., Sinclairella, 
434 Centetodon, Cormocyon, Cynarctoides, Phlaocyon, Daphoenodon, Arikareeomys, Moropus, and

435 Nanotragulus). At the same time, the Buda fauna and other Florida faunas of middle and late

436 Cenozoic age reflect a provinciality in which the relatively subtropical Gulf Coastal Plain

437 supported a different fauna from the Great Plains and other parts of temperate North America

438 (Albright, 1998). The new Florida apatemyid is a significant tie-in both to the Great Plains

439 faunas and the Gulf Coastal Plain endemism noted by several previous authors. Albright (1998,

440 see also references cited therein) summarized old and new evidence from Arikareean faunas

441 from Texas and Florida indicating an Arikareean and early Hemingfordian peak in regional

442 endemism of mammals in the subtropical Gulf Coastal Plain. While the mammalian fauna of this

443 region retained strong continuity with the developing grassland fauna in the northern Great

444 Plains, the coastal plain of the Gulf of Mexico provided a refugium for several genera and

445 species of subtropical-tropical forest-adapted mammals. As a Gulf Coastal endemic member of a

446 genus otherwise known only in late Eocene and early Oligocene northern Great Plains faunas,

447 Sinclairella simplicidens in the Buda LF of Florida lends additional support to Albright's (1998)

448 interpretation of Gulf Coastal Plain faunal endemism in the Arikareean.

449 Concomitant with retreat into a subtropical forest refugium, $S$. simplicidens might also

450 represent the end of the North American apatemyid lineage unless it or other apatemyids

451 occurred farther south into the tropics of Mexico and Central America. Several recently

452 discovered early Miocene (latest Arikareean and early Hemingfordian) vertebrate faunas from

453 Panama contain a moderate diversity of rodents and a bat, but lack apatemyids (MacFadden et

454 al., 2014). The general scarcity of apatemyids in the fossil record and the paucity of Middle

455 American late Oligocene and early Miocene faunas, except those from Panama, will impede

456 confirmation of this possibility until Middle American paleofaunas are much better known. 
458 Plains faunas, (reviewed by Albright, 1998:180; 2005). Albright (2005) noted an occurrence of

459 the distinctive primate Ekgmowechashala in the early late Arikareean (Ar3) Toledo Bend LF of

460 Texas as a 4-million-year temporal range extension, and a geographic extension from the

461 northern Great Plain to the Gulf Coastal Plain similar to our record of Sinclairella simplicidens

462 in Florida. However, Samuels, Albright \& Fremd (2015) recently questioned the identity of the

463 Toledo Bend specimen as Ekgmowechashala and determined that further study of it will be

464 necessary to determine its true identity. In the Buda LF Centetodon, Texomys, and Arikareeomys

465 probably represent either "holdovers" or Gulf Coast endemics. Centetodon and Sinclairella are

466 almost certainly holdovers that apparently survived in the Gulf Coastal Plain after their earlier

467 local extinction in the Great Plains. Texomys seems to be a Gulf Coastal (and Middle American)

468 endemic because it is currently known only from Panama, Texas, Louisiana, and Florida

469 (Albright, 1996; MacFadden et al., 2014). Arikareeomys is known primarily from Florida (four

470 Arikareean records), with the exception of the type locality - the McCann Canyon LF in

471 Nebraska of Korth (1992).

472 Gulf Coastal Plain faunas in the Arikareean and early Hemingfordian also reflect an

473 early, temporary expansion of the tropical Middle American fauna into this region (Webb, 1977;

474 MacFadden \& Webb, 1982; Albright, 1998). Several bat families with Neotropical affinities in

475 Florida late Oligocene and early Miocene faunas affirm this Neotropical link for at least these

476 volant mammals; the faunas and families include the Buda LF (Emballonuridae) and those from

477 I-75, Brooksville 2, and Thomas Farm (Emballonuridae, Mormoopidae, Speonycteridae, and

478 Natalidae; Morgan \& Czaplewski, 2003, 2012; Czaplewski \& Morgan, 2012). The bats are not

479 holdovers since none of these families are known in Great Plains Oligocene-early Miocene 
480 faunas (nor elsewhere on the continent). However, the Neotropical bats provide further evidence

481 that Florida, and presumably the remainder of the Gulf Coastal Plain, did provide a

482 subtropical/tropical refugium for certain mammals in the Arikareean and on into the early

483 Hemingfordian.

484

485 ACKNOWLEDGMENTS

486 We thank Richard Hulbert and S. David Webb, Florida Museum of Natural History, for

487 loaning us specimens and Roger Burkhalter for help in image processing. NJC wishes to thank

488 the Director of the Oklahoma Museum of Natural History for partial support of the research for

489 this project. Ken Rose, Mary Silcox, and Matthew Weiler provided helpful comments on an

490 earlier version of this manuscript.

491

492 REFERENCES

493 Albright LB. 1996. Insectivores, rodents, and carnivores of the Toledo Bend LF: An Arikareean

494 (earliest Miocene) assemblage from the Texas coastal plain. Journal of Vertebrate

$495 \quad$ Paleontology $16: 458-473$

496 Albright LB. 1998. The Arikareean land mammal age in Texas and Florida: southern extension

498

499

500 of Great Plains faunas and Gulf Coastal Plain endemism. In: Terry DO, LaGarry HE, Hunt RM, eds. Depositional environments, lithostratigraphy, and biostratigraphy of the White River and Arikaree Groups (late Eocene to early Miocene, North America). Geological Society of America Special Paper 325, 167-183

Albright LB. 1999. Ungulates of the Toledo Bend LF (late Arikareean, early Miocene), Texas coastal plain. Bulletin of the Florida Museum of Natural History 42:1-80 
503 Albright LB. 2005. Ekgmowechashala (Mammalia, ?Primates) from the Gulf Coastal Plain.

$504 \quad$ Bulletin of the Florida Museum of Natural History 45:355-361

505 Albright LB, Woodburne MO, Fremd T, Swisher CC, MacFadden BJ, and Scott GR. 2008.

506 Revised chronostratigraphy and biostratigraphy of the John Day Formation (Turtle Cove and Kimberly members), Oregon, with implications for updated calibration of the Arikareean North American Land Mammal Age. Journal of Geology 116:211-237

Beck RMD. 2009. Was the Oligo-Miocene Australian metatherian Yalkaparidon a 'mammalian woodpecker'? Biological Journal of the Linnean Society 97:1-17

511 Bloch JI, Boyer DM. 2001. Taphonomy of small mammals in freshwater limestones from the Paleocene of the Clarks Fork Basin. In: Gingerich PD, ed. Paleocene-Eocene

Cavin JL, Samuels JX. 2012. The first record of an apatemyid from Oregon: Sinclairella dakotensis from the Turtle Cove Member of the John Day Formation. Journal of Vertebrate Paleontology, Program and Abstracts, 2012, 76

518 Clemens WA. 1964. Records of the fossil mammal Sinclairella, Family Apatemyidae, from the Chadronian and Orellan. University of Kansas Publications, Museum of Natural History 14:483-491

Coombs MC, Hunt RM, Stepleton E, Albright LB, Fremd TJ. 2001. Stratigraphy, chronology, biogeography, and taxonomy of early Miocene small chalicotheres in North America.

524 Czaplewski NJ, Morgan GS. 2012. New basal noctilionoid bats (Mammalia: Chiroptera) from the Oligocene of subtropical North America. In: Gunnell G, Simmons NB, eds. 
Evolutionary history of bats: fossils, molecules, and morphology. Cambridge: Cambridge University Press, 162-209

528 Emry RJ. 1973. Stratigraphy and preliminary biostratigraphy of the Flagstaff Rim area, Natrona County, Wyoming. Smithsonian Contributions to Paleobiology 18:1-43

Frailey CD. 1978. An early Miocene (Arikareean) fauna from north-central Florida (the SB-1A local fauna). Occasional Papers of the Museum of Natural History, University of Kansas 75:1-20

Frailey CD. 1979. The large mammals of the Buda local fauna (Arikareean: Alachua County, Florida). Bulletin of the Florida State Museum Biological Sciences 24:123-173

Gingerich PD. 1982. Studies on Paleocene and early Eocene Apatemyidae (Mammalia,

Gingerich PD, Rose KD. 1982. Studies on Paleocene and early Eocene Apatemyidae (Mammalia, Insectivora). I. Dentition of Clarkforkian Labidolemur kayi. Contributions from the Museum of Paleontology, University of Michigan 26:49-55

542 Gunnell GF, Bown TM, Bloch JI, Boyer DM. 2008. "Proteutheria". In: Janis CM, Gunnell GF, Uhen MD, eds. Evolution of Tertiary mammals of North America, vol. 2. Cambridge: Cambridge University Press, 63-81

Hayes FG. 2000. The Brooksville 2 local fauna (Arikareean, latest Oligocene): Hernando County, Florida. Bulletin of the Florida Museum of Natural History 43:1-47 volume 2: small mammals, xenarthrans, and marine mammals. Cambridge: Cambridge 
550 Jepsen GL. 1934. A revision of the American Apatemyidae and the description of a new genus,

551 Sinclairella, from the White River Oligocene of South Dakota. Proceedings of the

$552 \quad$ American Philosophical Society 74:287-305

553 Koenigswald Wv., Schierning HP. 1987. The ecological niche of an extinct group of mammals, 554 the early Tertiary apatemyids. Nature 326:595-597

555 Koenigswald Wv, Rose KD, Grande L, Martin RD. 2005a. Die Lebensweise eozäner Säugetiere (Pantolestidae und Apatemyidae) aus Messel (Europa) im vergleich zu neuen skelettfunden aus dem Fossil Butte Member von Wyoming (Nordamerika). Geologisches Jahrbuch Hessen 132:43-54

Koenigswald Wv, Rose KD, Grande L, Martin RD. 2005b. First apatemyid skeleton from the Lower Eocene Fossil Butte Member, Wyoming (USA), compared to the European apatemyid from Messel, Germany. Palaeontographica Abteilung A 272:149-169

Koenigswald Wv, Ruf I, Gingerich PD. 2009. Cranial morphology of a new apatemyid, Carcinella sigei n. gen. n. sp. (Mammalia, Apatotheria) from the late Eocene of southern France. Palaeontographica Abteilung A 288:53-91

Korth WW. 1992. Fossil small mammals from the Harrison Formation (late Arikareean: earliest Miocene), Cherry County, Nebraska. Annals of Carnegie Museum 61:69-131 Eocene and younger species of Centetodon (Mammalia, Insectivora, Geolabididae) with a description of the dentition of Ankylodon (Adapisoricidae). University of Wyoming Publications 45:1-115

MacFadden BJ, Bloch JI, Evans H, Foster DA, Morgan GS, Rincon AF, Wood AR. 2014. 
Temporal calibration and biochronology of the Centenario Fauna, early Miocene of Panama. Journal of Geology 122:113-135

574 MacFadden BJ, Morgan GS. 2003. New oreodont (Mammalia, Artiodactyla) from the late Oligocene (early Arikareean) of Florida. Bulletin of the American Museum of Natural History 279:368-396

MacFadden BJ, Webb SD. 1982. The succession of Miocene (Arikareean through Hemphillian) terrestrial mammalian localities and faunas in Florida. In: Scott TM, and Upchurch SB, eds. Miocene of the southeastern United States. Tallahassee: Florida Department of Natural Resources, Bureau of Geology Special Publication 25, 186-199

Matthew WD. 1909. The Carnivora and Insectivora of the Bridger Basin, middle Eocene. Memoirs of the American Museum of Natural History 9:291-567

Matthew WD. 1921. Stehlinius, a new Eocene insectivore. American Museum Novitates 14:1-5

McKenna MC. 1963. Primitive Paleocene and Eocene Apatemyidae (Mammalia, Insectivora) and the primate-insectivore boundary. American Museum Novitates 2160:1-39

McKenna MC, Bell SK. 1997. Classification of mammals above the species level. New York: Columbia University Press

Morgan GS. 1993. Mammalian biochronology and marine-nonmarine correlations in the Neogene of Florida. Florida Geological Survey, Special Publication 37:55-66 Florida, with comments on natalid phylogeny. Journal of Mammalogy 84:729-752 record. In: Gunnell G, Simmons NB, eds. Evolutionary history of bats: fossils, molecules, and morphology. Cambridge: Cambridge University Press, 105-161 
595 Ostrander GE. 1985. Correlation of the early Oligocene (Chadronian) in northwestern Nebraska. 596 Dakoterra 2:205-231

597 Ostrander GE. 1987. The early Oligocene (Chadronian) Raben Ranch local fauna, northwest 598 Nebraska: Marsupialia, Insectivora, Dermoptera, Chiroptera, and Primates. Dakoterra 599 3:92-104

600

601

602

603

604 605 606 607 608 609

(Eocene: Chadronian), Bowman County, North Dakota. Proceedings of the North Dakota Academy of Sciences 49:65

Rich THV, Patton TH. 1975. First record of a fossil hedgehog from Florida (Erinaceidae: Mammalia). Journal of Mammalogy 56:692-695

Rincon AF, Bloch JI, MacFadden BJ, Jaramillo CA. 2015. New early Miocene protoceratids (Mammalia, Artiodactyla) from Panama. Journal of Vertebrate Paleontology DOI: $10.1080 / 02724634.2015 .970688$

Rose KD. 2006. The beginning of the Age of Mammals. Baltimore: Johns Hopkins University Press, $431 \mathrm{pp}$.

Russell DE, Godinot M, Louis P, Savage DE. 1979. Apatotheria (Mammalia) de l'Éocène inférieur de France et de Belgique. Bulletin Museum National d'Histoire Naturelle, Paris, sér. 4, 1:203-242

Samuels JX, Albright LB, Fremd TJ. 2015. The last fossil primate in North America, new material of the enigmatic Ekgmowechashala from the Arikareean of Oregon. American Journal of Physical Anthropology DOI: 10.1002/ajpa.22769

Scott WB, Jepsen GL. 1936. The mammalian fauna of the White River Oligocene. Part I. Insectivora and Carnivora. Transactions of the American Philosophical Society, new 
series, 28(1):1-153

619 Silcox MT, Bloch JI, Boyer DM, Houde P. 2010. Cranial anatomy of Paleocene and Eocene

620 Labidolemur kayi (Mammalia: Apatotheria), and the relationships of the Apatemyidae to 621 other mammals. Zoological Journal of the Linnean Society 160:773-825

622 Simpson GG. 1954. An apatemyid from the early Eocene of New Mexico. American Museum Novitates 1654:1-4

624 Simpson WF. 1985. Geology and paleontology of the Oligocene Harris Ranch badlands, southwestern South Dakota. Dakoterra 2:303-333

626

Slaughter BH. 1981. A new genus of geomyoid rodent from the Miocene of Texas and Panama. Journal of Vertebrate Paleontology 1:111-115

Storer JE. 1995. Small mammals of the Lac Pelletier Lower fauna, Duchesnean, of Saskatchewan, Canada: Insectivora and insectivore-like groups, a plagiomenid, a microsyopid and Chiroptera. In: Sarjeant WAS, ed. Vertebrate fossils and the evolution of scientific concepts. writings in tribute to Beverly Halstead, by some of his many friends. Gordon and Breach Publishers, United Kingdom, 595-615

Storer JE. 1996. Eocene-Oligocene faunas of the Cypress Hills Formation, Saskatchewan. IN: Prothero DR, Emry RJ, eds. The terrestrial Eocene-Oligocene transition in North America. Cambridge: Cambridge University Press, 240-261

Tedford RH, Galusha T, Skinner MF, Taylor BE, Fields RW, Macdonald JR, Rensberger JM, Webb SD, Whistler DP. 1987. Faunal succession and biochronology of the Arikareean through Hemphillian interval (late Oligocene through earliest Pliocene epochs) in North America. In: Woodburne MO, ed. Cenozoic mammals of North America: geochronology and biostratigraphy. Berkeley: University of California Press, 153-210 
641 Tedford RH, Swinehart JB, Swisher CC, Prothero DR, King SA, Tierney TE. 1996. The

642 Whitneyan-Arikareean transition in the High Plains. In: Prothero DR, Emry RJ, eds. The

643 terrestrial Eocene-Oligocene transition in North America. Cambridge: Cambridge

644 University Press, 312-334

645 Tedford RH, Albright LB, Barnosky AD, Ferrusquía-Villafranca I, Hunt RM, Storer JE, Swisher CC, Voorhies MR, Webb SD, Whistler DP. 2004. Mammalian biochronology of the Arikareean through Hemphillian interval (late Oligocene through early Pliocene epochs). In: Woodburne MO, ed. Late Cretaceous and Cenozoic mammals of North America: biostratigraphy and geochronology. New York: Columbia University Press, 169-231

Van Valen LM. 1966. Deltatheridia, a new order of mammals. Bulletin of the American Museum of Natural History 132:1-126.

Wang X, Tedford RH, Taylor BE. 1999. Phylogenetic systematics of the Borophaginae (Carnivora: Canidae). Bulletin of the American Museum of Natural History 243:1-391

Webb SD. 1977. A history of savanna vertebrates in the New World. Part 1: North America. Annual Review of Ecology and Systematics 8:355-380

West RM. 1973. Review of the North American Eocene and Oligocene Apatemyidae (Mammalia: Insectivora). Special Publications, Museum, Texas Tech University 3:1-42 intercontinental overland dispersals, sea level, climate, and vicariance. In: Berggren WA, Kent DV, Aubry MP, Hardenbol J, eds. Geochronology, time scales, and global stratigraphic correlation. Society of Sedimentary Geology, Special Publication 54, 335364 
664 TABLE 1.

665 Mammalian members of the Buda local fauna (from Frailey, 1979; Albright, 1998; Hayes, 2000; 666 and personal observation).

667

\begin{tabular}{|c|c|c|}
\hline Order & Family & Genus and species \\
\hline Apatotheria & Apatemyidae & Sinclairella simplicidens \\
\hline \multirow[t]{3}{*}{ Rodentia } & Jimomyidae & Texomys sp. \\
\hline & Heteromyidae & Proheteromys sp. \\
\hline & Eomyidae & Arikareeomys sp. \\
\hline Soricomorpha & Geolabididae & Centetodon cf. C. magnus \\
\hline Erinaceomorpha & Erinaceidae & Parvericius sp. \\
\hline Chiroptera & Emballonuridae & Undescribed genus and species \\
\hline \multirow[t]{6}{*}{ Carnivora } & Canidae (Borophaginae) & Phlaocyon achoros \\
\hline & & Cynarctoides lemur \\
\hline & & Cormocyon cf. C. copei \\
\hline & Amphicyonidae & Daphoenodon notionastes \\
\hline & Mustelidae & Genus indet. \\
\hline & Nimravidae & Genus indet. \\
\hline \multirow[t]{2}{*}{ Perissodactyla } & Equidae & Genus indet. \\
\hline & Chalicotheriidae & Moropus cf. M. oregonensis \\
\hline \multirow[t]{2}{*}{ Artiodactyla } & Tayassuidae & Cynorca sp. \\
\hline & Merycoidodontidae & Genus indet. \\
\hline
\end{tabular}




\begin{tabular}{|l|l|l|}
\hline & (Phenacocoelinae) & \\
\hline & Camelidae & Nothokemas sp. \\
\hline & & Genus indet. \\
\hline & Hypertragulidae & Nanotragulus loomisi \\
\hline
\end{tabular}

668

669

670

671 
673 TABLE 2.

674 Measurements (in mm) of upper molars of Sinclairella dakotensis from western North America 675 and Sinclairella simplicidens n. sp. from the Buda local fauna, Alachua County, Florida. The 676 measurements of $S$. dakotensis are taken from West (1973). APL = anteroposterior length; TW = 677 transverse width; $\mathrm{N}=$ sample size. Additional measurements as defined by von Koenigswald et 678 al. 2009) and in the text are provided for Sinclairella simplicidens (Width 2, Width 3, Width 4).

679

\begin{tabular}{|c|c|c|c|}
\hline tooth & measurement & Sinclairella simplicidens & Sinclairella dakotensis \\
\hline M1 & APL & $3.36(\mathrm{~N}=1)$ & $3.9-4.1(\mathrm{~N}=3)$ \\
\hline M1 & TW & $2.80(\mathrm{~N}=1)$ & $3.3-3.7(\mathrm{~N}=3)$ \\
\hline M1 & Width 2 & $2.90(\mathrm{~N}=1)$ & \\
\hline M1 & Width 3 & $3.10(\mathrm{~N}=1)$ & \\
\hline M1 & Width 4 & $4.10(\mathrm{~N}=1)$ & \\
\hline M2 & APL & $2.80-2.84(\mathrm{~N}=2)$ & $3.4-3.8(\mathrm{~N}=4)$ \\
\hline $\mathrm{M} 2$ & TW & $2.68-3.04(\mathrm{~N}=2)$ & $4.1-4.6(\mathrm{~N}=4)$ \\
\hline M2 & Width 2 & $3.10-3.20(\mathrm{~N}=2)$ & \\
\hline M2 & Width 3 & $2.90-3.10(\mathrm{~N}=2)$ & \\
\hline M2 & Width 4 & $3.70-3.80(\mathrm{~N}=2)$ & \\
\hline M3 & APL & $3.24(\mathrm{~N}=1)$ & $3.2(\mathrm{~N}=1)$ \\
\hline M3 & TW & $3.28(\mathrm{~N}=1)$ & $4.4(\mathrm{~N}=1)$ \\
\hline M3 & Width 2 & $3.60(\mathrm{~N}=1)$ & \\
\hline M3 & Width 3 & $3.20(\mathrm{~N}=1)$ & \\
\hline M3 & Width 4 & $4.20(\mathrm{~N}=1)$ & \\
\hline
\end{tabular}


683

684

685

686

687

688

689

690

PeerJ reviewing PDF | (2015:09:6607:2:0:NEW 20 Nov 2015) 


\section{FIGURE LEGENDS}

692 Figure 1. Map of North America showing the localities in which the apatemyid Sinclairella is

693 known. Dots represent occurrences of Sinclairella sp. and S. dakotensis; square represents

694 Sinclairella simplicidens. See text for a listing of localities other than Buda, Florida.

695

696 Figure 2. Biochronology of Miocene mammal taxa other than Sinclairella simplicidens occurring

697 in the Buda Local fauna, Florida, USA, as these taxa are known from North America. The chart 698 does not include their Buda occurrences.

699

700 Figure 3. Upper molars of Sinclairella simplicidens n. sp. A, UF 97383, right M2 (holotype) in

701 occlusal view ; B, UF 97385, right M1 in occlusal view; C, UF 97384, damaged right M2 in 702 occlusal view; D, UF 97382, left M3.

703

704 Figure 4. Occlusal outlines of upper molars of several North American apatemyids redrawn so

705 that M1s are same size (scale bars at right equal $1 \mathrm{~mm}$ ). A, Sinclairella simplicidens $\mathrm{n} . \mathrm{sp}$.

706 (composite molar row reconstructed from isolated teeth; see Fig. 2; M3 reversed); B, Sinclairella

707 dakotensis molar row redrawn from Jepsen (1934; YPM PU 13585; Chadronian); C, Stehlinella

708 (=Apatemys) uintensis M1-M2 redrawn from Matthew (1921; AMNH 1903; Uintan); D,

709 Apatemys sp. molar row drawn from McKenna (1963; USNM 17765; Wasatchian); E,

710 Labidolemur kayi M1-M2 redrawn from Gingerich and Rose (1982; UMMP 73496;

711 Clarkforkian).

712

713 
714 Figure 1. Map of North America showing the localities in which the apatemyid

715 Sinclairella is known. Dots represent occurrences of Sinclairella sp. and S. dakotensis;

716 square represents Sinclairella simplicidens. See text for a listing of localities other than

717 Buda, Florida.

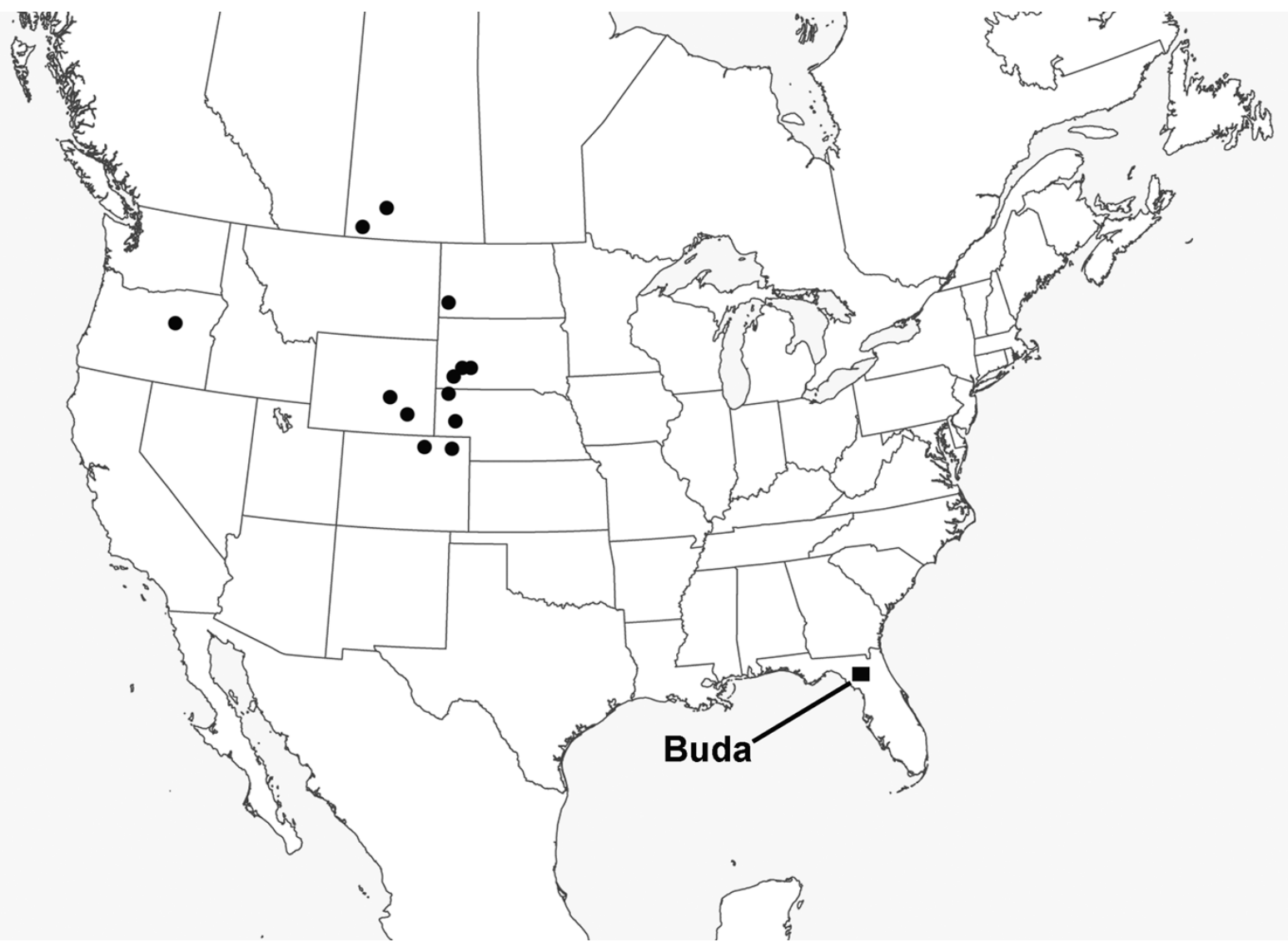

719 
720 Figure 2. Biochronology of Miocene mammal taxa other than Sinclairella simplicidens

721 occurring in the Buda Local fauna, Florida, USA, as these taxa are known from North

722 America. The chart does not include their Buda occurrences.

\begin{tabular}{|c|c|c|c|c|c|c|c|}
\hline Ma & 32 & 2 & $2 €$ & 24 & 22 & \multicolumn{2}{|c|}{18,16} \\
\hline Epoch & \multicolumn{4}{|c|}{ OLIGOCENE } & \multicolumn{3}{|c|}{ MIOCENE } \\
\hline NALMA & $\begin{array}{l}\text { Whit- } \\
\text { neyan }\end{array}$ & \multicolumn{4}{|c|}{ Arikareean } & $\begin{array}{l}\text { Heming- } \\
\text { fordian }\end{array}$ & Barstoviar \\
\hline subage & & Ar 1 & $\begin{array}{lll}\operatorname{Ar} 2 & \\
\end{array}$ & $\operatorname{Ar} 3$ & $\operatorname{Ar} 4$ & \begin{tabular}{l|l}
$\mathrm{He} 1$ & $\mathrm{He}$ \\
2
\end{tabular} & \begin{tabular}{l|l|l}
$\mathrm{He}$ & $\mathrm{Ba} 1$ & $\mathrm{Ba} 2$ \\
\end{tabular} \\
\hline \multicolumn{8}{|l|}{$\begin{array}{l}\text { Centetodon } \\
\text { cf. C. magnus }\end{array}$} \\
\hline \multicolumn{8}{|l|}{ Parvericius sp. } \\
\hline \multicolumn{8}{|l|}{ Texomys sp. } \\
\hline \multicolumn{8}{|l|}{ Proheteromys sp. } \\
\hline \multicolumn{8}{|l|}{ Arikareeomys sp. } \\
\hline \multicolumn{8}{|l|}{ Phlaocyon spp. } \\
\hline \multicolumn{8}{|l|}{ Cynarctoides lemur } \\
\hline \multicolumn{8}{|l|}{ Cormocyon cf. C. copei } \\
\hline \multirow{2}{*}{\multicolumn{8}{|c|}{$\begin{array}{l}\text { Daphoenodon sp. } \\
\text { Moropus } \\
\text { cf. } M \text {. oregonensis }\end{array}$}} \\
\hline & & & & & & & \\
\hline \multicolumn{8}{|l|}{ Nothokemas sp. } \\
\hline Nanotragulus loomisi & & & & & & & \\
\hline & 1 & 1 & 1 & & 1 & 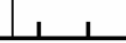 & \\
\hline
\end{tabular}


725 Figure 3. Upper molars of Sinclairella simplicidens n. sp. A, UF 97383, right M2

726 (holotype) in occlusal view; B, UF 97385, right M1 in occlusal view; C, UF 97384,

727 damaged right M2 in occlusal view; D, UF 97382, left M3.
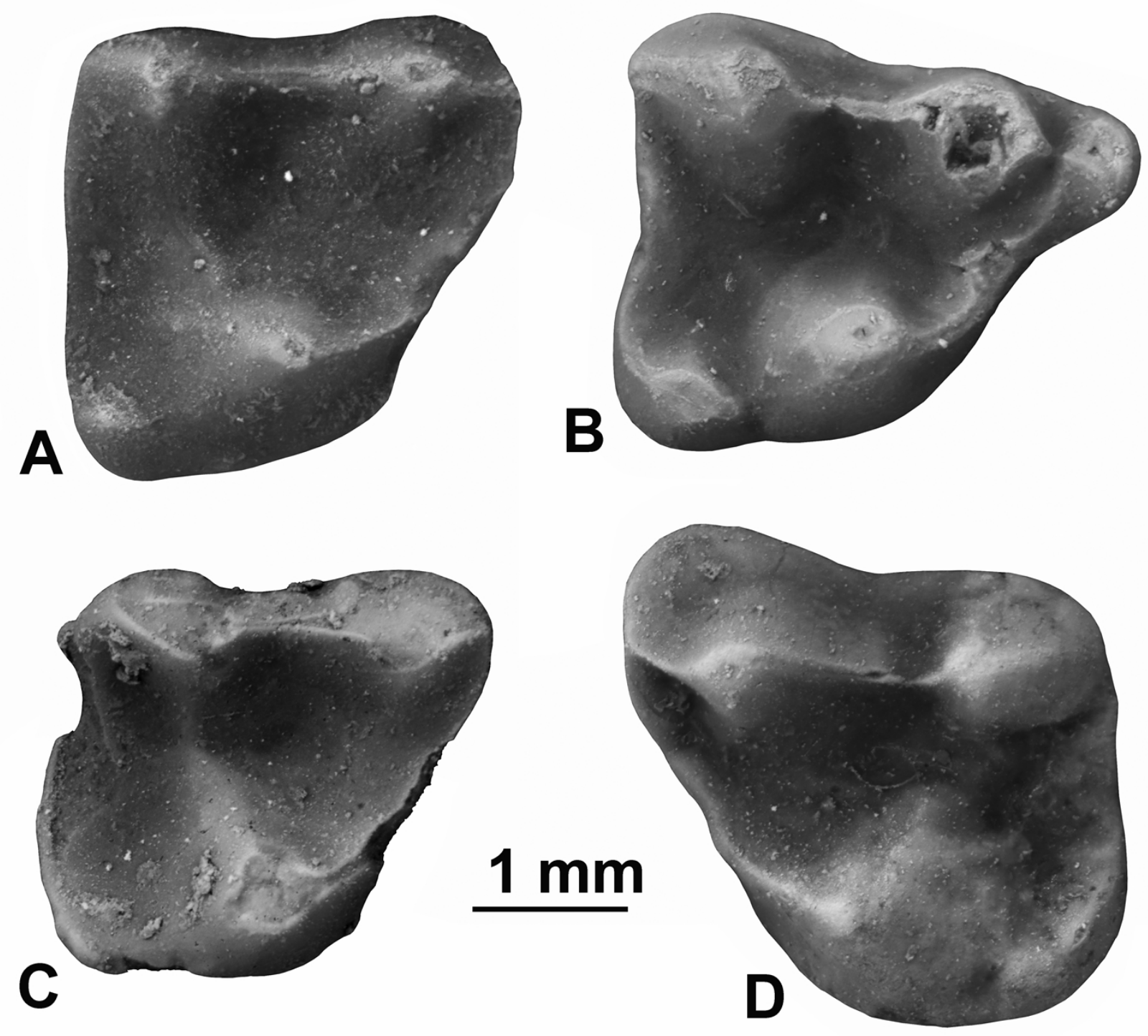
731 Figure 4. Occlusal outlines of upper molars of several North American apatemyids

732 redrawn so that $\mathrm{M} 1 \mathrm{~s}$ are same size (scale bars at right equal $1 \mathrm{~mm}$ ). A, Sinclairella

733 simplicidens n. sp. (composite molar row reconstructed from isolated teeth; see Fig. 3;

734 M3 reversed); B, Sinclairella dakotensis molar row redrawn from Jepsen (1934; YPM

735 PU 13585; Chadronian); C, Stehlinella (= Apatemys) uintensis M1-M2 redrawn from

736 Matthew (1921; AMNH 1903; Uintan); D, Apatemys sp. molar row drawn from McKenna

737 (1963; USNM 17765; Wasatchian); E, Labidolemur kayi M1-M2 redrawn from Gingerich

738 and Rose (1982; UMMP 73496; Clarkforkian). 

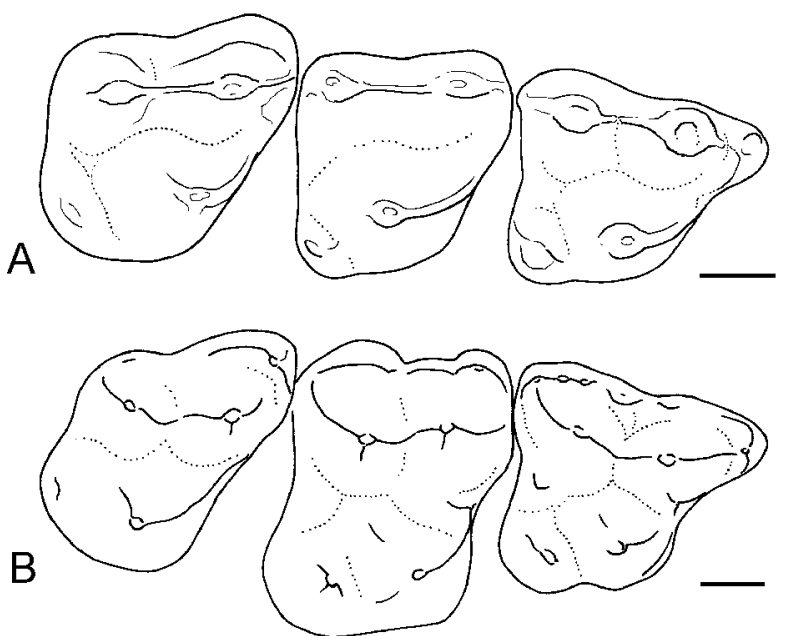

C

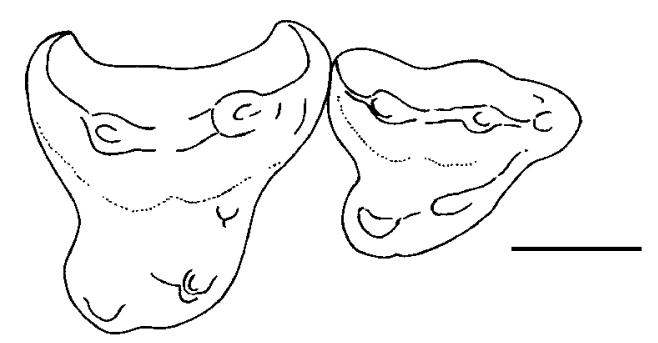

D

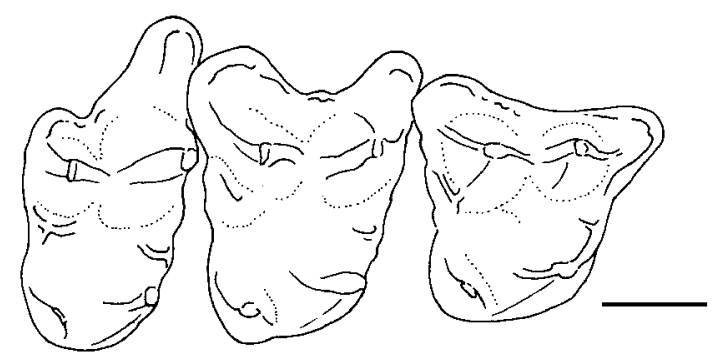

E

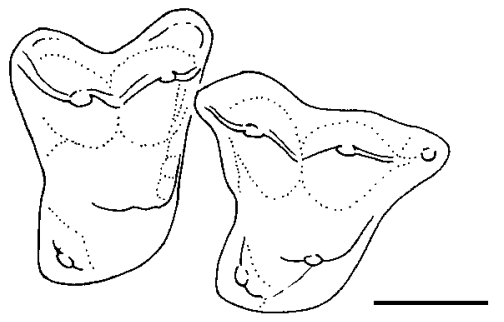

